\title{
Reaksi Pasar Atas Right Issue
}

\author{
Jacqueline Immanuele Firstiany ${ }^{1}$ \\ Dewa Gede Wirama ${ }^{2}$
}

\author{
${ }^{1,2}$ Fakultas Ekonomi dan Bisnis Universitas Udayana (Unud), Bali, Indonesia \\ e-mail: jacquelinemansoor@gmail.com
}

\begin{abstract}
ABSTRAK
Right issue merupakan salah satu corporate action yang dapat memengaruhi jumlah dan harga saham yang berada di pasar. Kandungan informasi dari pengumuman right issue menjadi penting, karena dapat membuat pasar bereaksi terhadap pengumuman tersebut. Penelitian ini bertujuan untuk menguji kandungan informasi pada peristiwa pengumuman right issue di Bursa Efek Indonesia dengan periode penelitian selama 10 tahun yaitu dari tahun 2008 sampai dengan 2017. Pengujian kandungan informasi suatu peristiwa seperti peristiwa pengumuman right issue umumnya menggunakan event study. Jendela peristiwa yang digunakan dalam penelitian ini adalah selama 5 hari dengan menggunakan marketadjusted model dalam menghitung abnormal return. Sampel penelitian ini berjumlah 146 perusahaan yang ditentukan dengan metode purposive sampling. Berbeda dari yang dihipotesiskan, hasil pengujian one sample t-test menunjukkan bahwa pasar tidak bereaksi atas pengumuman right issue.
\end{abstract}

Kata Kunci: Right issue, reaksi pasar, event study, market-adjusted model, abnormal return

\begin{abstract}
Right issue is one of corporate actions that can affect the number and price of shares in the market. The information content from the announcement of the rights issue becomes important, because it can make the market react to the announcement. This study aims to examine the information content of the announcement of the rights issue at the Indonesia Stock Exchange with a research period of 10 years, from 2008 to 2017. Testing the information content of an event such as the announcement of the rights issue generally uses event study. The event window used in this study is 5 days using market-adjusted model in calculating abnormal returns. The sample of this study is 146 companies which were determined by purposive sampling method. Different from those hypothesized, the results of the one sample t-test indicates that the market does not react to the announcement of rights issue.
\end{abstract}

Keywords: Right issue, market reaction, event study, market-adjusted model, abnormal return

\section{PENDAHULUAN}

Perusahaan publik menjadikan pasar modal sebagai wadah atau alternatif pemenuhan sumber pembiayaan perusahaan. Pasar modal merupakan pasar yang memperjualbelikan modal jangka panjang dalam bentuk surat berharga seperti 
obligasi dan saham (Kasmir, 2014:51). Perusahaan yang sudah terdaftar di pasar modal ada kalanya membutuhkan tambahan dana. Salah satu alternatif yang tersedia bagi perusahaan untuk mendapatkan tambahan dana adalah melalui penawaran saham baru. Penawaran saham ini pada umumnya disebut sebagai right issue karena pemegang saham lama diberi hak terlebih dahulu untuk membeli saham baru.

Aksi right issue dilakukan oleh perusahaan adalah untuk menghemat biaya emisi dan juga untuk menambah jumlah lembar saham yang diperdagangkan (Kandi, 2016). Alasan perusahaan untuk melakukan right issue sangat beragam, misalnya pembangunan pabrik baru, penambahan modal kerja, diversifikasi produk, pembayaran utang, atau untuk rencana pengembangan perusahaan di masa yang akan datang (Sandyaswari dan Yasa, 2016). Motivasi utama perusahaan melakukan penawaran saham kembali selain untuk mencukupi modal dan kas perusahaan adalah untuk meningkatkan investasi pada bidang research dan development (Bayless dan Nancy, 2013).

Right issue merupakan salah satu corporate action yang dapat memengaruhi jumlah dan harga saham yang berada di pasar. Corporate action merupakan kebijakan yang diambil perusahaan dengan tujuan untuk memperbaiki atau menunjukkan performance perusahaan untuk jangka panjang maupun jangka pendek (Ikhfana, 2015). Perusahaan yang melakukan corporate action harus memberitahukan keputusan tersebut kepada investor karena hal tersebut dapat memengaruhi komposisi kepemilikan sekuritas setelah pengumuman, sehingga 
investor harus melakukan analisis dampak dari corporate action tersebut agar kemudian dapat mengantisipasi dalam membuat keputusan yang tepat.

Right issue merupakan penerbitan saham baru oleh perusahaan yang dimana hak untuk membeli saham baru tersebut diberikan kepada pemegang saham lama (Kusuma dan Suryanawa, 2015). Di Indonesia, hak tersebut dikenal dengan istilah Hak Memesan Efek Terlebih Dahulu (HMETD). Right issue atau HMETD (Hak Memesan Efek Terlebih Dahulu) adalah produk turunan dari saham (Herlianto, 2013:16). Harga saham right issue biasanya lebih murah dari harga pasarnya. Hal ini dimaksudkan sebagai insentif bagi pemegang saham lama karena pemegang saham lama merupakan elemen penting bagi jalannya perusahaan.

Alasan utama perusahaan melakukan right issue adalah untuk melindungi kepentingan pemegang saham lama dan untuk melaksanakan hak preemptive. Hak preemptive merupakan hak bagi pemegang saham lama untuk membeli terlebih dahulu saham baru pada harga tertentu dalam waktu tertentu, biasanya kurang dari enam bulan. Penawaran pertama kali kepada pemegang saham lama dilakukan agar proporsi kepemilikan sahamnya masih tetap, sehingga pemegang saham lama dapat mempertahankan kekuasaannya dalam mengendalikan perusahaan.

Right bukan suatu kewajiban dan hanya bersifat hak (Aryasa dan Suaryana, 2017). Right issue merupakan hak bagi pemodal untuk membeli saham baru yang akan dikeluarkan emiten (Kurniawan dan Yasha, 2016). Pemegang saham lama memiliki hak untuk membeli atau memiliki saham baru dalam jumlah yang setara dengan saham yang mereka miliki sebelumnya. Menggunakan haknya 
dan membeli saham tambahan, menjual haknya, dan tidak melakukan apapun dan membiarkan hak tersebut kadaluarsa adalah 3 hal yang dapat dipilih pemegang saham saat mendapatkan right issue (Van Horne dan Wachowicz, 2007:328).

Jika didalam pelaksanannya ternyata harga tersebut berada di atas harga pasar, maka investor lebih cenderung akan menukarkan right dengan saham karena investor menilai harga saham lebih murah jika mereka beli di pasar (Fahmi dan Saputra, 2013). Pemegang saham lama yang tidak melakukan pembelian saham baru dapat menawarkan haknya kepada pihak lain yang mempunyai keinginan untuk membeli saham perusahaan tersebut. Akibat yang akan diterima dari pemegang saham lama yang tidak melakukan konversi rights-nya adalah persentasi kepemilikan sahamnya akan mengalami penurunan atau mengalami dilusi (dilution).

Konsep pasar efisien ditekankan pada aspek informasi, artinya pasar yang efisien merupakan pasar dimana harga semua sekuritas yang diperjualbelikan mencerminkan semua informasi yang tersedia dipasar (Tandelilin, 2010:219). Pasar modal yang efisien dapat didefinisikan sebagai pasar yang harga sekuritasnya telah mencerminkan semua informasi yang relevan. Informasi yang ada tersebut meliputi semua informasi baik informasi yang berasal dari masa lampau maupun informasi saat ini dan juga informasi yang dinyatakan dalam bentuk pendapat atau opini rasional yang beredar di pasar. Informasi-informasi ini bisa memengaruhi harga saham.

Semakin cepat informasi baru tercermin pada harga sekuritas akan semakin efisien pasar modal tersebut, maka akan sangat sulit bagi para pemodal 
untuk memperoleh tingkat keuntungan di atas normal secara konsisten dengan melakukan transaksi perdagangan di Bursa Efek. Efisiensi dalam artian ini sering juga disebut sebagai efisiensi pasar secara informasi yaitu bagaimana pasar bereaksi terhadap informasi yang tersedia (Hartono, 2017:606). Jadi, harga saham yang berlaku di pasar modal sudah merefleksikan semua informasi yang ada.

Terdapat tiga macam bentuk utama dari efisiensi pasar berdasarkan ketiga macam bentuk informasi, yaitu informasi masa lalu, informasi masa sekarang yang sedang di publikasi dan informasi privat sebagai berikut (Fama, 1970): pasar dikatakan efisien dalam bentuk lemah jika harga-harga dari sekuritas tercermin secara penuh (fully reflect) informasi masa lalu. Informasi masa lalu ini merupakan informasi yang sudah terjadi. Bentuk efisiensi pasar secara lemah ini berkaitan dengan teori langkah acak (random walk theory) yang menyatakan bahwa data masa lalu tidak berhubungan dengan nilai sekarang. Jika pasar efisien secara bentuk lemah, maka nilai-nilai masa lalu tidak dapat digunakan informasi untuk memprediksi harga sekarang. Ini berarti bahwa untuk pasar efisien bentuk lemah, investor tidak dapat menggunakan informasi masa lalu untuk mendapatkan keuntungan yang tidak normal atau abnormal return.

Pasar dikatakan efisien setengah kuat jika harga-harga sekuritas secara penuh mencerminkan (fully reflect) semua informasi yang dipublikasikan (all publicly available information) termasuk informasi yang dipublikasikan dapat berupa: 1) Informasi yang dipublikasikan hanya memengaruhi harga sekuritas dari perusahaan yang mempublikasikan informasi tersebut. Informasi yang dipublikasikan ini merupakan informasi dalam bentuk pengumuman oleh 
perusahaan emiten. Informasi ini umumnya berhubungan dengan peristiwa yang terjadi di perusahaan emiten. 2) Informasi yang dipublikasikan hanya memengaruhi harga-harga sekuritas sejumlah perusahaan. Informasi yang dipublikasikan ini dapat berupa peraturan pemerintah atau peraturan dari regulator yang hanya berdampak pada harga sekuritas perusahaan-perusahaan yang terkena dampak regulasi tersebut. 3) Informasi yang dipublikasikan memengaruhi harga sekuritas semua perusahaan yang terdaftar di pasar saham. Informasi ini dapat berupa peraturan pemerintah atau peraturan dari regulator yang berdampak pada semua perusahaan emiten.

Pasar dikatakan efisien dalam bentuk kuat jika harga-harga sekuritas secara penuh mencerminkan semua informasi yang tersedia termasuk informasi privat. Jika pasar efisien dalam bentuk ini, maka tidak ada individual investor atau grup dari investor yang dapat memperoleh keuntungan tidak normal karena mempunyai informasi privat.

Kandungan informasi dari pengumuman right issue menjadi penting, karena akan membuat pasar bereaksi terhadap pengumuman tersebut. Pengumuman right issue yang dinilai oleh investor memiliki kandungan informasi yang sangat berharga akan membuat pasar bereaksi setelah diterimanya pengumuman tersebut. Untuk menguji kandungan informasi suatu peristiwa seperti peristiwa pengumuman right issue biasanya menggunakan event study. Event study adalah studi yang mengamati reaksi pasar terhadap suatu peristiwa yang informasinya dipublikasikan sebagai suatu pengumuman. Event study juga dapat diartikan sebagai menganalisis reaksi pasar terhadap harga suatu sekuritas. 
Reaksi akibat dilakukannya right issue dapat dibagi menjadi dua yaitu reaksi positif maupun reaksi negatif. Reaksi positif akan dapat mendorong harga saham menjadi meningkat, hal ini dapat dilihat ketika para investor melakukan pembelian. Jika reaksi suatu peristiwa bersifat negatif terhadap harga saham di pasar, maka artinya peristiwa tersebut tidak dikehendaki oleh investor (Apsari dan Yasa, 2017). Reaksi pasar bisa dilihat dari ada atau tidaknya abnormal return yang signifikan di seputar tanggal pengumuman peristiwa.

Abnormal return adalah peristiwa dimana terjadi suatu kelebihan dari return yang sesungguhnya terjadi terhadap return normal (Hartono, 2017:667). Return normal merupakan return ekspektasian (return yang diharapkan oleh investor). Return harapan tersebut dapat diestimasi dengan menghitung rata-rata tertimbang return harapan dari masing-masing aset individual yang ada dalam suatu portofolio (Tandelilin, 2010:120). Abnormal return akan terjadi setiap harinya pada setiap jenis saham, yaitu dimana selisih antara actual return dan expected return yang bisa dihitung secara harian (Samsul, 2006:276).

Selisih return akan positif jika return yang didapatkan lebih besar dari return yang diharapkan atau return yang dihitung, sedangkan return akan negatif jika return yang didapatkan lebih kecil dari return yang diharapkan atau return yang dihitung. Suatu pengumuman yang mengandung informasi akan memberikan abnormal return kepada investor dan sebaliknya peristiwa yang tidak mengandung informasi tidak akan memberikan abnormal return kepada investor (Pratama dan Sudhiarta, 2014). 
Penelitian terdahulu mengenai right issue banyak dilakukan tetapi masih menunjukkan hasil yang berbeda. Penelitian yang dilakukan oleh Ramesh dan Rajumesh (2014) di Colombo memperoleh hasil bahwa terdapat pola dominan AAR yang positif di sekitar periode peristiwa. Hasil empiris menunjukkan bahwa terdapat AAR positif sebesar $1,54 \%$ yang secara statistik signifkan pada hari 0 (pada saat pengumuman). Widagdo (2015) menyatakan bahwa terdapat abnormal retrun positif signifikan terbesar terjadi pada hari -3 . Pada hari pengumuman right issue, abnormal return masih positif tetapi tidak signifikan.

Berbeda dengan hasil penelitian sebelumnya Endriani (2015) menemukan bahwa nilai rata-rata abnormal return pada hari $\mathrm{t}+5$ hingga $\mathrm{t}-5$ hari setelah pengumuman right issue tidak signifikan. Hal ini menunjukkan bahwa pengumuman tersebut tidak mengandung informasi karena pengumuman tersebut tidak direaksi oleh pasar. Hasil penelitian Apsari dan Yasa (2017) menyatakan bahwa terdapat reaksi pasar negatif sebelum pengumuman right issue. Hal tersebut dapat dikarenakan adanya kebocoran informasi pada perusahaan yang akan melakukan pengumuman right issue. Namun tidak terdapat adanya reaksi pasar pada saat pengumuman right issue resmi dikeluarkan. Susanti dan Ardiana (2014) serta Kiremu dkk., (2013) menyatakan bahwa pengumuman right issue tidak memiliki kandungan informasi. Bashir (2013) meneliti pada perusahaan yang melakukan right issue dalam periode 2008-2011 di Bursa Efek Karachi (KSE). Penelitian ini menemukan bahwa terdapat abnormal return positif pada saat event date. Hasil yang diperoleh menunjukkan bahwa adanya peningkatan abnormal return sebesar $0,41 \%$ pada tanggal pengumuman, tetapi peningkatan 
kekayaan dari pemegang saham tersebut tidak signifikan secara statistik. Penelitian ini menyimpulkan bahwa tidak terdapat reaksi pasar di Karachi Stock Market terhadap pengumuman right issue.

Penelitian lain yang dilakukan oleh Nisak (2015) menunjukkan bahwa pada 3 hari sebelum pengumuman right issue terjadi penurunan harga saham karena investor beranggapan bahwa pengumuman right issue tersebut sebagai suatu berita buruk (bad news). Penelitian yang dilakukan di luar Indonesia oleh Ginglinger dkk., (2013) dan Mateus dkk., (2017) mendapatkan hasil bahwa pengumuman right issue dilihat sebagai bad news oleh investor pada pasar modal. Hasil yang sama ditemui dalam penelitian yang dilakukan oleh Lee dkk., (2014) dalam penelitiannya menemukan bahwa investor bereaksi negatif terhadap pengumuman penawaran right di Hong Kong dan abnormal return dari penawaran right issue pada hari pengumuman adalah $-12.10 \%$. Otieno dan Ochieng (2015) menyatakan bahwa pengumuman right issue memberikan efek negatif terhadap return saham pada perusahaan yang terdaftar di National Stock Exchange. Kendirli dan Elmali (2016) menemukan Cumulative Average Abnormal Returns (CAAR) negatif sepuluh hari setelah tanggal pengumuman.

Penawaran saham kembali yang dilakukan perusahaan mengindikasikan bahwa kurangnya sumber pembiayaan lain atau bahkan perusahaan dalam kondisi keuangan yang buruk (Happ dan Schiereck, 2017). Right issue merupakan bad news bagi investor yang menginginkan keuntungan jangka pendek. Pengumuman right issue yang dilakukan oleh perusahaan dianggap sebagai pengumuman yang bersifat bad news, sehingga investor lebih tertarik untuk menjual kepemilikan 
sekuritasnya dibandingkan melakukan investasi kembali dengan cara membeli sekuritas (Dewi, 2014). Nilai saham akan turun akibat pasar bereaksi negatif terhadap pengumuman right issue (Otieno dan Ochieng, 2015). Setelah pengumuman right issue harga saham secara teoritis akan mengalami penurunan, hal ini disebabkan harga saham right issue akan lebih rendah dari harga pasar (Ruli dkk., 2014).

Reaksi negatif investor atas pengumuman right issue sesuai dengan pecking order theory. Pecking order theory menyatakan perusahaan memiliki preferensi dalam memilih sumber pendanaan dengan mempertimbangkan biaya termurah dan risiko paling kecil. Berdasarkan pecking order theory, tidak terdapat struktur modal yang optimal. Teori ini menyatakan bahwa dalam membiayai pengembangan usahanya, perusahaan lebih menyukai penggunaan dana yang bersumber dari internal daripada eksternal.

Sumber dana internal yang dimaksud adalah laba ditahan dan cadangan depresiasi aktiva tetap. Perusahaan lebih menyukai sumber dana internal karena tidak perlu mengungkapkan sejumlah informasi kepada pihak eksternal berupa prospektus perusahaan (Noor, 2015). Pendanaan internal memiliki keuntungan, yaitu tidak memerlukan biaya penerbitan dan tidak perlu memberikan informasi mengenai kondisi keuangan perusahaan, seperti kesempatan investasi yang potensial dan keuntungan yang diharapkan bila kesempatan investasi tersebut diambil.

Apabila perusahaan mengalami defisit dalam pendanaan internalnya maka akan lebih mendahulukan sumber dana eksternal berupa utang daripada 
menerbitkan sekuritas ekuitas. Urutan atau hierarki pendanaan berdasarkan teori pecking order adalah sebagai berikut (Radjamin dan Sudana, 2014): 1) Pendanaan internal yang berasal dari laba ditahan. 2) Penggunaan utang dengan menerbitkan obligasi. 3) Penerbitan saham.

Prioritas pendanaan ini dibentuk berdasarkan pendanaan yang paling murah. Penentuan sumber pendanaan dilakukan untuk memperoleh keuntungan yang menjadi tujuan awal pendirian sebuah perusahaan (Nurcahayani dan Daljono, 2014). Beberapa asumsi yang digunakan terhadap perilaku pendanaan perusahaan dalam pecking order theory adalah sebagai berikut (Myers, 1984): 1) Perusahaan lebih menyukai pendanaan yang bersumber dari hasil operasi perusahaan (internal financing). 2) Perusahaan mencoba menyesuaikan rasio pembagian dividen yang ditargetkan dengan berusaha menghindari perubahan secara drastis dalam pembayaran dividen. 3) Kebijakan dividen yang konstan, ditambah dengan fluktuasi profitabilitas dan peluang investasi yang tidak bisa diduga, mengakibatkan dana hasil operasi terkadang melebihi kebutuhan dana untuk investasi, meskipun pada kesempatan yang lain mungkin kurang. Apabila dana hasil operasi kurang dari kebutuhan investasi, maka perusahaan akan mengurangi saldo kas atau menjual surat berharga. 4) Apabila pendanaan dari luar (external financing) diperlukan, maka perusahaan akan menerbitkan sekuritas yang paling aman terlebih dahulu, dimulai dengan penggunaan utang yaitu melalui penerbitan obligasi, kemudian oleh sekuritas yang berkarakteristik opsi seperti obligasi konversi, dan menerbitkan saham baru sebagai pilihan terakhir. 
Peningkatan penggunaan utang cenderung direspon sebagai suatu good news dan penerbitan sekuritas ekuitas sebagai suatu bad news (Dewi dan Wirama, 2017). Adanya peningkatan jumlah penggunaan utang memberi keyakinan pada investor bahwa hal tersebut merupakan cara perusahaan menyampaikan informasi mengenai keyakinan manajemen atas laba perusahaan di masa depan, sehingga tidak perlu mengkhawatirkan pembayaran utang dan biaya bunga atas utang tersebut.

Terdapat dua motivasi yang melandasi perusahaan lebih menyukai sumber dana dari utang. Pertama, perusahaan akan mendapat keuntungan dari selisih bunga atas sebagian besar utang jumlahnya tetap dan pengembalian aset operasi bersih. Kedua, perusahaan mendapatkan manfaat pajak atas penggunaan utang karena beban bunga utang dapat mengurangi pajak. Alasan lainnya terkait dengan penghindaran dilusi kepemilikan saham dan perusahaan dengan utang yang membayar bunga tetap akan lebih menguntungkan dalam kondisi suku bunga yang naik.

Pecking order theory juga menjelaskan mengenai terjadinya asimetri informasi atas penggunaan sumber dana eksternal antara manajemen perusahaan dan investor, dimana informasi yang lebih komprehensif mengenai kondisi perusahaan saat ini dan prospek masa depan perusahaan hanya dimiliki oleh salah satu pihak, yaitu manajemen perusahaan (Dewi dan Wirama, 2017). Manajer khawatir apabila melakukan penerbitan saham baru akan ditafsirkan sebagai tanda buruk oleh investor, sehingga akan membuat harga saham perusahaan turun. 
Beberapa studi empiris mengenali pola pendanaan sesuai pecking order theory sudah dilakukan pada beberapa negara, yaitu Mahardhika dan Aisjah (2013) membuktikan perusahaan di Indonesia mengikuti pola pendanaan sesuai pecking order theory. Chang dan Song (2013) yang meneliti pada perusahaan elektronik di Hongkong serta Laisi, (2016) yang meneliti pada perusahaanperusahaan Eropa Utara juga dapat membuktikan bahwa pola pendanaan yang digunakan adalah berdasarkan pecking order theory.

Pernyataan di atas juga di dukung oleh penelitian-penelitian terdahulu yang memberikan hasil bahwa pengumuman right issue akan di reaksi negatif oleh pasar. Nisak (2015) menunjukkan bahwa pada 3 hari sebelum pengumuman right issue terjadi penurunan harga saham karena investor beranggapan bahwa pengumuman right issue tersebut sebagai suatu berita buruk (bad news). Penelitian yang dilakukan di luar Indonesia oleh Ginglinger et al., (2013) dan Mateus et al., (2017) mendapatkan hasil bahwa pengumuman right issue dilihat sebagai bad news oleh investor pada pasar modal. Hasil yang sama ditemukan dalam penelitian yang dilakukan oleh Lee et al., (2014), Otieno dan Ochieng (2015) bahwa pengumuman right issue memberikan efek negatif. Kendirli dan Elmali (2016) menemukan Cumulative Average Abnormal Returns (CAAR) negatif sepuluh hari setelah tanggal pengumuman.Berdasarkan teori dan penelitian pendahuluan yang telah diuraikan, maka hipotesis adalah:

$\mathrm{H}_{1}$ : Pasar bereaksi negatif atas pengumuman right issue pada perusahaan yang terdaftar di Bursa Efek Indonesia pada tahun 2008-2017. 


\section{METODE PENELITIAN}

Pendekatan yang digunakan dalam penelitian ini adalah studi peristiwa atau event study. Studi peristiwa merupakan studi yang mempelajari reaksi pasar terhadap suatu peristiwa (event) yang informasinya dipublikasikan sebagai suatu pengumuman. Event study digunakan untuk menguji kandungan informasi dari suatu pengumuman di seputar tanggal peristiwa. Peristiwa yang diuji dalam penelitian ini adalah pada saat perusahaan mengumumkan right issue dengan menggunakan jendela peristiwa selama 5 hari. Informasi dari pengumuman right issue akan diuji terhadap reaksi pasar yang diproksikan dengan cumulative abnormal return.

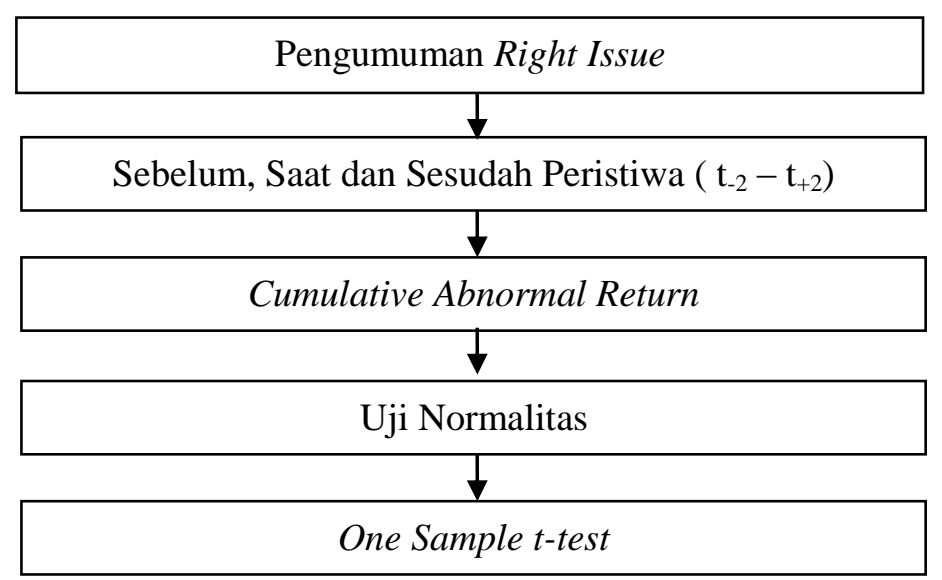

Gambar 1. Desain Penelitian

Sumber: Data diolah, 2018

Lokasi atau ruang lingkup wilayah penelitian ini dibatasi pada perusahaan yang terdaftar di Bursa Efek Indonesia yang menerbitkan right issue pada tahun 2008-2017. Data perusahaan dapat diakses melalui situs www.idx.co.id periode 2008-2017, www.ksei.co.id, serta data harga saham harian yang didapat melalui situs www.finance.yahoo.com. 
Objek penelitian ini adalah abnormal return atas pengumuman right issue pada perusahaan yang terdaftar di Bursa Efek Indonesia tahun 20082017. Penelitian ini menggunakan data dengan periode yang cukup panjang yaitu sepuluh tahun yang bertujuan agar mendapatkan hasil dari penelitian yang lebih akurat dan representatif.

Variabel independen dalam penelitian ini adalah pengumuman right issue. Variabel dependen dalam penelitian ini adalah reaksi pasar modal, yang dihitung berdasarkan abnormal return. Penelitian ini menggunakan market adjusted model untuk mengestimasi return ekspektasian, maka tidak perlu menggunakan periode estimasi untuk membentuk model estimasi, karena return sekuritas yang diestimasi sama dengan return pasar. Penelitian ini menggunakan event study dengan waktu periode pengamatan selama 5 hari yaitu pada 2 hari sebelum pengumuman right issue (t-2), 1 hari pada saat pengumuman right issue $(\mathrm{t}=0)$ dan 2 hari sesudah pengumuman right issue $(\mathrm{t}+2)$. Penggunaan periode pengamatan ini bertujuan untuk mengurangi potensi terjadinya confounding effect yaitu selama periode pengamatan tidak ada kebijakan lain yang dapat menyebabkan perubahan harga atau return saham, untuk mengantisipasi kemungkinan informasi peristiwa right issue sudah keluar ke publik terlebih dahulu karena adanya insider information, dan agar data yang telah diperoleh dapat mencerminkan keadaan yang sebenarnya.

Langkah-langkah untuk menghitung akumulasi abnormal return adalah sebagai berikut:

Actual return (Hartono, 2017:284) 


$$
R_{i, t}=\frac{P_{i, t}-P_{i, t-1}}{P_{i, t-1}}
$$

Keterangan:

$R_{i, t} \quad=$ Return sesungguhnya terjadi pada sekuritas ke-i pada periode ke-t

$P_{i, t} \quad=$ Harga saham relatif sekarang

$P_{i, t-1} \quad=$ Harga saham sebelumnya.

Menghitung expected return (Hartono, 2017:574)

$$
E\left[R_{i, t}\right]=\frac{I H S G_{t}-I H S G_{t-1}}{I H S G_{t}}
$$

Keterangan:

$E\left[R_{i, t}\right] \quad=$ Expected Return sekuritas ke-i pada periode ke- $\mathrm{t}$

$I H S G_{t} \quad=$ Indeks harga saham gabungan penutupan pada hari ke - $\mathrm{t}$

$I H S G_{t-1}=$ Indeks harga saham gabungan penutupan pada hari ke t-1

Abnormal return (Hartono, 2017:668)

$$
A R_{i, t}=R_{i, t}-E\left[R_{i, t}\right]
$$

Keterangan:

$A R_{i, t} \quad=$ Abnormal return sekuritas ke-i pada periode ke-t

$R_{i, t} \quad=$ Actual return yang terjadi untuk sekuritas ke-i pada periode ke-t

$E\left[R_{i, t}\right] \quad=$ Return ekspektasian sekuritas ke-i untuk periode ke-t

Menghitung cumulative abnormal return

$$
C A R_{i, t}=\sum A R_{i . t}
$$

Populasi pada penelitian ini adalah seluruh perusahaan publik yang terdaftar di Bursa Efek Indonesia dan melakukan corporate action berupa right issue selama periode pengamatan yaitu tahun 2008-2017. Populasi penelitian ini adalah sebanyak 262 perusahaan. Sampel adalah bagian dari jumlah karakteristik yang dimiliki oleh populasi (Sugiyono, 2015:168). Sampel pada penelitian ini adalah perusahaan publik yang terdaftar di Bursa 
Efek Indonesia dan melakukan corporate action berupa right issue selama periode pengamatan yaitu tahun 2008-2017 dan telah dipilih menggunakan metode non-probability sampling dengan teknik purposive sampling.

Pada teknik purposive sampling pemilihan sampel akan berdasarkan beberapa kriteria, dimana kriteria yang digunakan untuk memilih sampel adalah sebagai berikut: 1) Perusahaan terdaftar di Bursa Efek Indonesia dan melakukan corporate action berupa right issue pada periode 1 Januari 2008 sampai 31 Desember 2017. 2) Perusahaan tidak menerbitkan corporate action lainnya seperti stock split, merger dan akuisisi yang dapat memengaruhi abnormal return selama periode pengamatan right issue untuk menghindari adanya confounding effect. 3) Perusahaan memiliki data yang lengkap yang dapat mendukung penelitian ini seperti tanggal RUPS/RUPSLB dan saham tersebut aktif diperdagangkan selama 5 hari (2 hari sebelum pengumuman, 1 hari pengumuman dan 2 hari setelah pengumuman right issue) disekitar periode pengumuman right.

Tabel 1.

Proses dan Hasil Seleksi Sampel

\begin{tabular}{|c|c|c|}
\hline No & Kriteria & Jumlah \\
\hline 1 & Perusahaan melakukan right issue pada tahun 2008-2017. & 262 \\
\hline 2 & $\begin{array}{l}\text { Perusahaan melakukan corporate action lain (stock split, merger, dan akuisisi) } \\
\text { selama periode jendela (event window). }\end{array}$ & (24) \\
\hline 3 & $\begin{array}{l}\text { Perusahaan tidak memiliki data-data yang lengkap untuk mendukung } \\
\text { penelitian ini. }\end{array}$ & (92) \\
\hline & Jumlah Sampel & 146 \\
\hline
\end{tabular}

Sumber: Data diolah, 2018

Data penelitian yang telah diambil oleh peneliti harus diuji terlebih dahulu untuk mengetahui karakterisik dari data tersebut, salah satu pengujian yang dilakukan adalah dengan uji normalitas data. Uji normalitas bertujuan 
untuk menguji apakah dalam model regresi variabel pengganggu atau residual memiliki distribusi normal (Ghozali, 2013:160). Untuk menguji normalitas suatu data dapat dilakukan dengan menggunakan statistik non parametrik dengan uji satu sampel Kolmogorov-Smirnov (Utama, 2014:11). Hasil dari uji K-S ini menyatakan: 1) Nilai signikansi > 0,05 berarti data berdistribusi normal. 2) Nila i signikansi $<0,05$ berarti data tidak berdistribusi normal.

Teknik analisis data yang digunakan dalam penelitian ini one sample ttest. Syaratnya adalah data berupa kuantitatif dan memiliki distribusi normal (Rafela, 2016). Uji hipotesis dengan menggunakan one sampel t-test ini digunakan untuk menguji terdapat atau tidaknya reaksi pasar yang signifikan atas pengumuman right issue yang dilihat dari abnormal return pada sekitar pengumuman right issue. Tingkat signifikansi yang dimaksud yakni abnormal return secara statistik signifikan tidak sama dengan nol (positif untuk good news dan negatif untuk bad news). Pedoman untuk mengambil keputusan adalah dengan tingkat kepercayaan $95 \%$ atau $\alpha=5$ dengan kriteria sebagai berikut: 1 ) Nilai signifikan $\leq 0,05$ maka $\mathrm{H}_{0}$ ditolak dan $\mathrm{H}_{1}$ diterima. 2) Nilai signifikan >0,05 maka $\mathrm{H}_{0}$ diterima dan $\mathrm{H}_{1}$ ditolak.

\section{HASIL DAN PEMBAHASAN}

Jumlah sampel yang digunakan sebagai data penelitian ini pada awalnya sebanyak 262 perusahaan, namun 17 perusahaan dikeluarkan karena terdeteksi sebagai outlier, sehingga sampel yang digunakan dalam penelitian ini adalah sejumlah 129 perusahaan. 
Tabel 2.

Hasil Uji Statistik Deskriptif

\begin{tabular}{lrrrrr}
\hline & N & Minimum & Maximum & Mean & Std. Deviation \\
\hline CAR & 129 & -.0985 & .1191 & .0077 & .0475 \\
Valid N (listwise) & 129 & & & & \\
\hline \multicolumn{2}{l}{ Sumber: Data Diolah, 2018 } & & & &
\end{tabular}

Berdasarkan hasil dari Tabel 2 dapat dilihat bahwa secara statistik cumulative abnormal return (CAR) yang dilakukan selama 5 hari pengamatan dengan 129 perusahaan yang digunakan memperoleh hasil nilai CAR minimum sebesar -0,0985 yang dimiliki oleh Centratama Telekomunikasi Indonesia Tbk PT (CENT). Nilai maksimum CAR sebesar 0,1191 dimiliki oleh Bhuwanatala Indah Permai Tbk PT (BIPP). Nilai rata-rata CAR sebesar 0,0077 dengan standar deviasi sebesar 0,0475 .

Tabel 3.

Hasil Uji Normalitas

\begin{tabular}{llr}
\hline & & CAR \\
\hline $\mathrm{N}$ & & 129 \\
Normal Parameters & Mean & .0077 \\
& Std. Deviation & .0475 \\
Most Extreme Differences & Absolute & .065 \\
& Positive & .065 \\
& Negative & -.048 \\
Test Statistic & & .065 \\
Asymp. Sig. (2-tailed) & & .200
\end{tabular}

Sumber: Data diolah, 2018

Dari Tabel 3 dapat diketahui nilai dari signifikansi (asymptotic sig) dari cumulative abnormal return (CAR) atas pengumuman right issue sebesar 0,200> 0,05 , yang berarti bahwa data berdistribusi normal, sehingga dapat diteruskan analisisnya ke dalam uji one sample t-test.

Pengujian hipotesis ini menggunakan uji one sample t-test yang diolah dengan software IBM SPSS Statistics 23. Hasil uji hipotesis 1 dapat dilihat dalam Tabel 4. 
Tabel 4.

Uji One Sample t-test

Test Value $=0$

\begin{tabular}{|c|c|c|c|c|c|c|}
\hline & \multicolumn{6}{|c|}{ Test Value $=0$} \\
\hline & & & & & $\begin{array}{l}\text { 95\% Confiden } \\
\text { the Diff }\end{array}$ & $\begin{array}{l}\text { nterval of } \\
\text { nce }\end{array}$ \\
\hline & t & Df & Sig. (2-tailed) & Mean Difference & Lower & Upper \\
\hline CAR & 1,832 & 128 & ,069 & ,0077 &,- 0006 & ,016 \\
\hline
\end{tabular}

Sumber: Data diolah, 2018

Berdasarkan tabel uji one sample t-test diperoleh cumulative abnormal return nilai t sebesar 1,832 dengan nilai probabilitas sebesar $0,069>\alpha(0,05)$, yang menunjukkan bahwa tidak terdapat reaksi pasar atas pengumuman right issue, atau $\mathrm{H}_{1}$ ditolak dan $\mathrm{H}_{0}$ diterima.

Berdasarkan pengujian hipotesis yang telah dilakukan melalui uji one sample t-test dengan nilai t sebesar 1,832, dapat disimpulkan bahwa hipotesis 1 yaitu pasar bereaksi negatif atas pengumuman right issue ditolak, yang pasar tidak bereaksi atas pengumuman right issue. Hasil penelitian ini menunjukkan bahwa selama 5 hari pengamatan pengumuman right issue tidak memiliki kandungan informasi yang berharga yang dapat memengaruhi investor dalam membuat keputusan berinvestasinya.

Hasil dari penelitian ini sejalan dengan penelitian sebelumnya yaitu: Endriani (2015) menemukan bahwa nilai rata-rata abnormal return pada hari $\mathrm{t}+5$ hingga t-5 hari setelah pengumuman right issue tidak signifikan. Hal ini menunjukkan bahwa pengumuman tersebut tidak mengandung informasi karena pengumuman tersebut tidak menyebabkan terjadinya reaksi pasar. Susanti dan Ardiana (2014) menyatakan bahwa pengumuman right issue tidak memiliki kandungan informasi. Bashir (2013) meneliti pada perusahan yang melakukan right issue dalam periode 2008-2011 di Bursa Efek Karachi (KSE). Penelitian ini 
menemukan bahwa terdapat abnormal return positif pada saat event date. Hasil yang diperoleh menunjukkan bahwa adanya peningkatan abnormal return sebesar 0,41\% pada tanggal pengumuman, tetapi peningkatan kekayaan dari pemegang saham tersebut tidak signifikan secara statistik. Penelitian ini menyimpulkan bahwa tidak terdapat reaksi pasar di Karachi Stock Market terhadap pengumuman right issue.

Implikasi teoritis hasil penelitian ini adalah diketahuinya pengumuman right issue tidak direaksi oleh pasar. Penelitian ini juga dapat digunakan sebagai sumber referensi bagi penelitian selanjutnya, karena pengumuman right issue tidak mendukung pecking order theory.

Implikasi praktis dari penelitian ini adalah investor tidak perlu memerhatikan pengumuman right issue yang dilakukan oleh perusahaan karena pasar tidak bereaksi atas pengumuman right issue.

\section{SIMPULAN}

Berdasarkan hasil pengujian dan analisis yang telah dilakukan sebelumnya, maka dapat ditarik kesimpulan sebagai berikut: selama 5 hari perdagangan saham disekitar tanggal pengumuman right issue dengan menggunakan variabel cumulative abnormal return (CAR) tanpa melibatkan confounding effect seperti stock split, merger dan akuisi menunjukkan bahwa pengumuman right issue tidak di reaksi oleh pasar. Hal tersebut dapat dilihat dari hasil pengujian hipotesis 1 dengan menggunakan uji one sample t-test didapatkan nilai t sebesar 1,832 dengan probabilitas sebesar 0,069 >0,05. Berarti pengumuman right issue tidak 
mengandung informasi yang berharga yang dapat memengaruhi investor dalam membuat keputusan berinvestasi.

Berdasarkan simpulan yang sudah dipaparkan, maka saran-saran yang dapat diberikan bagi investor adalah meskipun pecking order theory menyatakan bahwa pengumuman right issue merupakan bad news, investor tidak perlu terpaku dengan pendapat pecking order theory karena kenyataannya tidak ada reaksi atas pengumuman right issue. Bagi peneliti-peneliti selanjutnya diharapkan dapat meneliti kembali dengan menggunakan model perhitungan abnormal return yang lainnya.

\section{REFERENSI}

Apsari, I. A. W. P., dan Yasa, G. W. 2017. Analisis Reaksi Pasar terhadap Pengumuman Right Issue pada Perusahaan Go Public yang Tercatat di BEI. E-Jurnal Akuntansi Universitas Udayana, 18(2), 1343-1368.

Aryasa, I. P. G. C. A., dan Suaryana, I. G. N. A. 2017. Reaksi Pasar Sebelum dan Sesudah Pengumuman Right Issue. E-Jurnal Akuntansi Universitas Udayana, 18(2), 1426-1454.

Bashir, A. 2013. Impact of Right Issues Announcement on Shareholders Wealth : Case Study of Pakistani Listed Companies. International Journal of Contemporary Business Studies, 4(3), 6-12.

Bayless, M., \& Nancy, J. 2013. What Motivates Seasoned Equity Offerings? Evidence from The Use of Issue Proceeds. Managerial Finance, 39(3), 251 271.

Chang, H., \& Song., F. M. 2013. Testing The Pecking Order Theory with Financial Constraints. SSRN Electronic Journal The University of Hongkong, $1(1), 1-44$.

Darajati, T. S., dan Hartomo, D. D. 2015. Struktur Modal Sektor Perbankan pada Saat Krisis Keuangan. Jurnal Bisnis \& Manajemen, 15(1), 17-32. 
Dewi, A. T. 2014. Studi Empiris Abnormal Return Sebelum dan Sesudah Pengumuman Right Issue pada Perusahaan Go Public di Bursa Efek Indonesia. E-Jurnal Manajemen Universitas Udayana, 3(11), 2423-2450.

Dewi, P. S. M. Y., dan Wirama, D. G. 2017. Pecking Order Theory: Pengaruh Profitabilitas dan Pertumbuhan Perusahaan pada Keputusan Pendanaan Perusahaan. E-Jurnal Akuntansi Universitas Udayana, 18(3), 2423-2450.

Endriani, S. 2015. Pengaruh Pengumuman Right Issue terhadap Return Saham pada Perusahaan Manufactur yang terdapat di Bursa Efek Indonesia. Jurnal Pendidikan Ekonomi, 1(1), 1-7.

Fahmi, I., and Saputra, M. 2013. Analysis of Profitability Ratio in Publishing Right Issue Decision at Indonesia Stock Exchange. International Journal of Business and Social Science, 4(4), 272-280.

Fama, E. F. 1970. Efficient Capital Markets: A Review of Theory and Empirical Work. Journal of Finance, 25(2), 383-417.

Ginglinger, E., Matsoukis, L., and Riva, F. 2013. Seasoned Equity Offerings: Stock Market Liquidity and the Rights Offer Paradox. Journal of Business Finance and Accounting, 40(1-2), 215-238.

Happ, C., and Schiereck, D. 2017. Seasoned Equity Offerings and Corporate Governance in Europe. Journal of European Real Estate Research, 1(2), 124.

Hartono, J. 2017. Teori Portofolio dan Analisis Investasi, edisi kesebelas. Yogyakarta: BPFE Yogyakarta.

Herlianto, D. 2013. Manajemen Investasi Plus Jurus Mendeteksi Investasi Bodong. Yogyakarta: Gosyen Publishing.

Ikhfana, A. N. 2015. Analisis Reaksi Pasar Sebelum dan Sesudah Pengumuman Right Issue terhadap Abnormal Return dan Aktivitas Volume Perdagangan pada Perusahaan yang Termasuk Indeks Saham Syariah Indonesia Tahun 2011-2014. Skripsi. Sarjana Jurusan Keuangan Islam pada Fakultas Syari’ah dan Hukum Universitas Islam Negeri Sunan Kalijaga, Yogyakarta.

Kandi, R. 2016. Analisis Return Saham Sebelum dan Sesudah Pengumuman Right Issue pada Perusahaan Perbankan yang Terdaftar di Bursa Efek Indonesia (Tahun 2010 - 2014). Jurnal Minds:Manajemen Ide Dan Inspirasi, 3(1), 7085.

Kasmir. 2014. Pengantar Manajemen Keuangan. Jakarta: Kencana Prenada Media Grup. 
Kendirli, S., and Elmali, M. E. 2016. The Effects of Right Offering Announcements on Returns of Shares of Deposit Banks Traded in Istanbul Stock-Exchange. Journal of Economic Development, Environment and People, 5(1), 74-82.

Kiremu, M. K. G., Galo, N., Wagala, A., \& James Kinyua Mutegi. 2013. Stock Price and Volumes Reaction to Annual Earnings Announcement: A Case of the Nairobi Securities Exchange. International Journal of Business, Humanities and Technology, 3(2), 100-111.

Kurniawan, I. S., dan Yasha, E. 2016. Reaksi Pasar dan Kinerja Keuangan pada Perusahaan Sebelum dan Sesudah Pengumuman Right Issue pada Perusahaan yang Melakukan Right Issue di Bursa Efek Indonesia. Junal Manajemen, $8(2), 181-200$.

Kusuma, P. S. A. J., \& Suryanawa, I. K. 2015. Analisis Komparatif Kinerja Saham Sebelum dan Sesudah Pengumuman Right Issue. E-jurnal Akuntansi Universitas Udayana, 12(3), 566-581.

Lee, C. C., Poon, W. C., and Sinnakkannu, J. 2014. Why are Rights Offers in Hong Kong So Different? Pacific Basin Finance Journal, 26, 176-197.

Mahardhika, B. P., dan Aisjah, S. 2013. Pengujian Pecking Order Theory dan Trade Off Theory pada Struktur Modal Perusahaan. Skripsi. Sarjana Manajemen Keuangan pada Fakultas Ekonomi dan Bisnis Universitas Brawijaya, Malang.

Mateus, C., Farinha, J., and Soares, N. 2017. Price Discounts in Rights Issues: Why do Managers Insist on What Investors Hate? European Business Review, 29(4), 457-475.

Myers, S. C. 1984. Capital Structure Puzzle. The Journal of Finance, 39, 575592.

Nisak, F. U. 2015. Analisis Reaksi Pasar Modal terhadap Pengumuman Right Issue pada Perusahaan Go Public di Bursa Efek Indonesia Tahun 2009-2013. Skripsi. Sarjana Jurusan Manajemen pada Fakultas Ekonomi, Universitas Negeri Yogyakarta, Yogyakarta.

Noor, T. 2015. Pengujian Pecking Order Theory dan Analisis Pengaruh Karakteristik Perusahaan terhadap Struktur Modal Emiten Sektor Pertanian. Tesis. Pascasarjana pada Fakultas Manajemen dan Bisnis Institut Pertanian Bogor, Bogor. 
Nurcahayani, R., dan Daljono. 2014. Analisis Pengaruh Struktur Modal terhadap Profitabilitas (Studi pada Perusahaan Manufaktur yang Terdaftar di Bursa Efek Indonesia pada Tahun 2010-2012). Diponegoro Journal of Accounting, $3(4), 1-10$.

Otieno, O. D., and Ochieng, D. E. 2015. The Effects of Rights Issue Announcements on Stock Returns for Firms Listed at The Nairobi Securities Exchange. International Journal of Education and Research, 3(9), 411-426.

Pratama, I. G. S., dan Sudhiarta, G. M. 2014. Analisis Perbandingan Abnormal Return Saham Sebelum dan Sesudah Pengumuman Right Issue. E-Jurnal Manajemen Universitas Udayana, 3(1), 243-257.

Radjamin, I. J. P., dan Sudana, I. M. 2014. Penerapan Pecking Order Theory dan Kaitannya dengan Pemilihan Struktur Modal Perusahaan pada Sektor Manufaktur di Negara Indonesia dan Negara Australia. Jurnal Manajemen Bisnis Indonesia, 1(3), 451-468.

Rafela, P. (2016). Analisis Perbedaan Abnormal Return Sebelum dan Sesudah Pengumuman Peringkat Obligasi di Indonesia. Skripsi. Sarjana Ekonomi pada Fakultas Ekonomi dan Bisnis Universitas Lampung, Bandar Lampung.

Ramesh, and Rajumesh. 2014. Information Content of Right Issue Announcements : A Study of Listed Companies in Colombo Stock Exchange of Sri Lanka. Journal of Finance and Accounting, 5(5), 154-162.

Ruli, R. P., DP, E. N., dan Hariyani, E. 2014. Pengaruh Pengumuman Right Issue Terhadap Return Saham, Abnormal Return, Frekuensi Perdagangan, Volume Perdagangan, Risiko Saham dan Kapitalisasi Pasar pada Perusahaan Property, Real Estate and Building Construction yang Terdaftar di BEI Tahun 2008-2011. Journal of Management FEKON, 1(2), 1-15.

Samsul, M. 2006. Pasar Modal dan Manajemen Portofolio. Jakarta: Penerbit Erlangga.

Sandyaswari, N. P., dan Yasa, G. W. 2016. Indikasi pada Manajemen Laba Perusahaan yang Melakukan Right Issue dan Pengaruhnya terhadap Kinerja Perusahaan. E-Jurnal Akuntansi Universitas Udayana, 15(1), 378-406.

Sugiyono. 2015. Metode Penelitian Bisnis. Bandung: CV Alfabeta.

Susanti, P. A., dan Ardiana, P. A. 2014. Reaksi Pasar terhadap Pengumuman Right Issue pada Perusahaan Warrant Issuer dan Non Warrant Issuer. EJurnal Akuntansi Universitas Udayana, 9(1), 221-236. 
Jacquiline Immanuele Firstiany dan Dewa Gede Wirama. Reaksi ...

Tandelilin, E. 2010. Portofolio dan Investasi Teori dan Aplikasi. Yogyakarta: Penerbit Kanisius.

Van Horne, J. C., dan Wachowicz, J. M. 2007. Fundamentals of Financial. Management, Prinsip-Prinsip Manajemen Keuangan. Jakarta: Salemba.

Widagdo, D. 2015. Analisis Faktor-faktor yang Mempengaruhi Reaksi Investor di Sekitar Pengumuman Right Issue. Jurnal Manajemen Dirgantara, 8(2), 117. 